\title{
MATRIX OF THE KEY COMPONENTS IN EACH OF THE ORIGINAL INDEPENDENT LIVING GRANTEE CURRICULA
}

\author{
Anita P. Barbee \\ University of Louisville, Kent School of Social Work
}

Jenny A. Taylor

University of Louisville, Kent School of Social Work

\section{Becky F. Antle}

University of Louisville, Kent School of Social Work

\section{Dana J. Sullivan}

University of Louisville, Kent School of Social Work

\section{Miriam Landsman}

University of Iowa, School of Social Work

\author{
Patricia C. Gilbaugh \\ University of Iowa, School of Social Work
}

Acknowledgement: This study was funded by two Federal training grants to the first and fifth authors from the U.S. DHHS, Administration for Children, Youth and Families, Children's Bureau, 90CW1134 and 90CW1133, respectively. Comments concerning this manuscript should be directed to anita.barbee@ louisville.edu.

It is vital when developing a curriculum to embark on a systematic review of several types of information. Generally, in the Children's Bureau training demonstration grants, the curriculum developers 1) develop an advisory board of members who work with the project team in conducting background research, create an outline of subjects to be covered, write modules, offer exercises, and critique the evaluation tools and final product. These advisory board members usually have expertise that can help the team do a better job than they would alone such as practice experience, knowledge of the literature, knowledge of the training process, how to write curricula, and how to manage the workforce that will be implementing the suggested practices included in the curricula. In addition curriculum developers 2) conduct a review of the literatures that relate to the topic of the training. In this case the relevant literatures included such topics as positive youth development, collaboration with and on behalf of youth, building relationships with youth, and working in a culturally competent way with youth. They 3) collect and review other curricula on the topic and often curricula on a particular topic already exist. These curricula may or may not 
be geared towards the new audience, but could have a wealth of good information in them to help in deciding what to include or exclude in a new curriculum. These curricula also can serve as a source of valuable information for the creation of refresher courses, on-line courses, and think pieces to give to workers; 4) study the various ways of laying out a curriculum. There are numerous models of how to write learning objectives, chose or create exercises, incorporate different adult learning styles into the curriculum and write a lesson plan that any trainer could pick up and follow. Once that study has occurred the project team can choose an approach such as 5) conducting focus groups with key constituencies who will be affected by the curriculum including case supervisors, front line workers whom the supervisors oversee, managers who are responsible for the work of the supervisor's teams, and most importantly, the youth that will be served after supervisors and staff are training. Finally, 6) actually synthesizing all of the information from the advisory board, focus groups, research literature, training manuals and curriculum building theories into writing the curriculum manual for both the trainer and the trainees.

\section{Curricula Matrices}

The focus of this paper is on the review of other curricula on a topic. Our grant cluster was at an advantage in that 12 grantees before us had created curricula on serving youth aging out of care aimed at front line workers. So, while the audience was different, much of the content would be relevant for our supervisory audiences. Thus, in order to get a handle on the content of these previous curricula ourselves, in a systematic way, and to help our fellow grantees with a product that could aid them in sorting through a massive amount of materials, staff from the University of Iowa and the University of Louisville created a set of matrices that summarized the contents of 10 of the previous 12 curricula into categories that were of interest to the current group of grantees. Two of the curricula (Eastern Michigan and South Carolina) were unavailable. The matrices follow. What is important to know in reading the matrices is that the top row describes the overarching area of interest. We covered four areas based on the RFP including Cultural Competence, Permanent Connection, Collaboration, and Youth Development. The left most column describes the institution that created a curriculum with some notations as to whether or not PowerPoint slides and/or extensive notes are included in the curriculum. The subsequent columns describe the sub-categories of information that were covered (or not) in that institution's curriculum. Comments are added to further explain what the institution did on this topic and key areas of interest. All curricula were and still can be accessed on the National Child Welfare Resource Center for Youth Development website at http://www.nrcys.ou.edu/yd/resources/publications.html. 


\section{Curricula S.W.O.T. Analyses}

While the matrices are helpful in getting a quick look at the 10 viable curricula, the review team also wrote extensive notes on each curriculum. The approach used was to conduct a modified S(trengths) W(eaknesses) O(pportunities for ideas) $\mathrm{T}$ (raining techniques) S.W.O.T. Analysis for each one. The curricula are critiqued in the order they appear on the matrices above.

\section{Boston University}

Strengths: The training is broken down into ten nicely organized modules with clearly defined objectives and time lines. Modules 5 and 6 look at transitioning to independence and offers ideas to encourage youth engagement (i.e. Decide, Obtain, Maintain, Grow-DOMG in Module 6, p.6, DOMG is the concept that Boston College uses in its framework for information gathering and transition planning education). This training hits nicely on all four core principles and sprinkles in conversation boxes of "Youth's Views" on varying topics (usually found in each training Module) while stressing the Positive Youth Development theory (focused on in Module 1, but found throughout regarding how all topics can be applied to PYD).

Weaknesses: Collaborations with community groups and services is not clearly defined, yet provides more of a focus on collaborations between the youth and their worker (Module 5, p.10). Permanent connections are addressed regarding positive social connections and less with creating long-term relationships with helping adults, with minimal attention to maintaining ties to foster and biological families. This training also does not stress the "hard skills" needed for successful transitions. And although youth voices are included, this training is facilitated by professionals.

Opportunities for ideas: This training brings back the ever-useful Eco-Map (Module 7, p.9) to help youth look at current supports and where support may be lacking. The use of case vignettes (Module 6, pp.8-11 and Module 3) are helpful to practice training objectives in the moment, while using the Fish Bowl exercise (Module 7, pp.13-14) allows the opportunity to hear a variety of participant voices in a controlled manner.

Training techniques: Many positive training techniques are used here to reinforce the Boston model including those mentioned above, as well as large and small discussion groups in nearly all Modules, role plays (Module 2, p.4), handouts, flipcharts and small group or individual activities, like the one in Module 2 (p.3) in helping participants recognize the multiple cultural memberships we possess to help us to better understand ourselves and assist our youth in their transition journey. 
Table 1: Cultural Competence

\begin{tabular}{|c|c|c|c|c|c|c|c|c|c|}
\hline Institution & $\underset{\widetilde{\pi}}{\tilde{\pi}}$ & 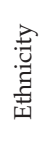 & $\underset{<}{80}$ & 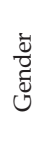 & 吕 & 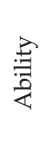 & 占 & 章 & Comments \\
\hline Boston U & $\mathrm{Y}$ & $\mathrm{Y}$ & $\mathrm{Y}$ & $\mathrm{Y}$ & $\mathrm{Y}$ & $\mathrm{Y}$ & $\mathrm{N}$ & $\mathrm{N}$ & $\begin{array}{l}\text { Focus placed on many areas of culture, } \\
\text { including youth struggling with issues of } \\
\text { sexuality and ways to be sensitive to their } \\
\text { experiences as well as ethnicity, race, age, } \\
\text { etc. }\end{array}$ \\
\hline U of Denver & $\mathrm{Y}$ & $\mathrm{Y}$ & $\mathrm{Y}$ & $\mathrm{Y}$ & $\mathrm{Y}$ & Y & $\mathrm{Y}$ & $\mathrm{Y}$ & $\begin{array}{l}\text { "We to Me" is a module on cultural compe- } \\
\text { tence identifying major cultures and several } \\
\text { subcultures. "Cultural Mix" module teaches } \\
\text { participants about the ways culture influ- } \\
\text { ences transitioning youth. }\end{array}$ \\
\hline Fordham U & $\mathrm{Y}$ & $\mathrm{Y}$ & $\mathrm{Y}$ & $\mathrm{Y}$ & $\mathrm{N}$ & $\mathrm{N}$ & $\mathrm{N}$ & $\mathrm{N}$ & $\begin{array}{l}\text { Cultural competence focuses on the use of } \\
\text { "isms" in society and to raise consciousness } \\
\text { and sensitivity to the "isms". }\end{array}$ \\
\hline U Kansas - ${ }^{*} \mathbf{N}$ & $\mathrm{N}$ & $\mathrm{N}$ & $\mathrm{Y}$ & $\mathrm{N}$ & $\mathrm{N}$ & $\mathrm{N}$ & $\mathrm{N}$ & $\mathrm{N}$ & $\begin{array}{l}\text { Culture is not discussed. Age is mentioned } \\
\text { as point in time when things should occur. }\end{array}$ \\
\hline $\begin{array}{l}\text { U of Southern } \\
\text { Maine - } \mathbf{N}\end{array}$ & $\mathrm{N}$ & $\mathrm{N}$ & $\mathrm{N}$ & $\mathrm{N}$ & $\mathrm{N}$ & $\mathrm{N}$ & $\mathrm{N}$ & $\mathrm{N}$ & $\begin{array}{l}\text { Culture is only mentioned in terms of youth } \\
\text { identity. }\end{array}$ \\
\hline $\begin{array}{l}\text { U of North } \\
\text { Carolina - N }\end{array}$ & $\mathrm{N}$ & $\mathrm{N}$ & $\mathrm{N}$ & $\mathrm{N}$ & $\mathrm{N}$ & $\mathrm{N}$ & $\mathrm{N}$ & $\mathrm{N}$ & $\begin{array}{l}\text { Culture is not discussed in these terms. Cur- } \\
\text { riculum looks at culture as a societal force } \\
\text { not the make-up of the youth. }\end{array}$ \\
\hline $\begin{array}{l}\text { U of Oklahoma, } \\
\text { NRCYS }-{ }^{*} N\end{array}$ & $\mathrm{Y}$ & $\mathrm{Y}$ & $\mathrm{Y}$ & $\mathrm{N}$ & $\mathrm{N}$ & $\mathrm{N}$ & $\mathrm{N}$ & $\mathrm{Y}$ & $\begin{array}{l}\text { Cultural competence focuses on Native } \\
\text { Americans with a special emphasis on } \\
\text { embracing tribal traditions. Discusses elder- } \\
\text { youth mentoring, but no age-specific issues. }\end{array}$ \\
\hline $\begin{array}{l}\text { San Diego } \\
\text { State U }-{ }^{*} \mathbf{N}\end{array}$ & $\mathrm{Y}$ & Y & Y & $\mathrm{Y}$ & $\mathrm{N}$ & $\mathrm{Y}$ & $\mathrm{Y}$ & $\mathrm{Y}$ & $\begin{array}{l}\text { Cultural component in this training ad- } \\
\text { dresses all major issues from a youth point } \\
\text { of view (p. 47-58) in a Mezzo context. }\end{array}$ \\
\hline $\begin{array}{l}\text { San Francisco } \\
\text { State U }\end{array}$ & $\mathrm{Y}$ & Y & $\mathrm{N}$ & $\mathrm{N}$ & $\mathrm{Y}$ & Y & Y & $\mathrm{N}$ & $\begin{array}{l}\text { Includes competency training for LGBT } \\
\text { populations. Module on challenging values } \\
\text { on p. 85-89. Categorizes people into groups } \\
\text { of "privilege" and "underprivileged" (p. } \\
\text { 96-97). }\end{array}$ \\
\hline SUNY - * & $\mathrm{N}$ & $\mathrm{N}$ & $\mathrm{N}$ & $\mathrm{N}$ & $\mathrm{N}$ & $\mathrm{N}$ & $\mathrm{Y}$ & $\mathrm{N}$ & $\begin{array}{l}\text { No discussions of cultural competence in } \\
\text { this training-brief look at sexuality and } \\
\text { discovery. }\end{array}$ \\
\hline
\end{tabular}

Race/Ethnicity - addresses bias related to racelethnicity and/or how to work with youth of different backgrounds

SES - addresses differences in socio-economic issues

Age - addresses bias related to age

Gender-addresses bias related to gender

SES - trains on information regarding socio-economic status and biases in SES

Ability - addresses working with youth of varying ability/disability

LGBT - addresses issues youth are dealing with regarding sexuality

Spirit/Relig - addresses issues related to spirituality and religion

* = PowerPoint electronically available $\mathbf{N}=$ Detailed notes are available 
Table 2: Permanent Connection

\begin{tabular}{|c|c|c|c|c|c|}
\hline Institution & 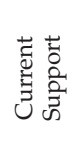 & 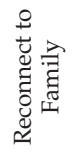 & 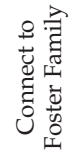 & 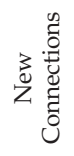 & Comments \\
\hline Boston $\mathrm{U}$ & Y & $\mathrm{N}$ & $\mathrm{N}$ & Y & $\begin{array}{l}\text { These issues are briefly touched on, but more focus } \\
\text { on positive social supports with less focus on long } \\
\text { term permanent connection. }\end{array}$ \\
\hline $\mathrm{U}$ of Denver & Y & Y & Y & $\mathrm{Y}$ & $\begin{array}{l}\text { Trains on minimizing negative connections while } \\
\text { maximizing the positives and how to assess the } \\
\text { quality of connections. }\end{array}$ \\
\hline Fordham U & $\mathrm{Y}$ & $\mathrm{N}$ & $\mathrm{N}$ & $\mathrm{N}$ & $\begin{array}{l}\text { Very little is added in this training about creating } \\
\text { and maintaining permanent connections. }\end{array}$ \\
\hline U of Kansas - * & $\mathrm{Y}$ & Y & $\mathrm{Y}$ & $\mathrm{Y}$ & $\begin{array}{l}\text { Builds upon relationship with worker and foster } \\
\text { parents strongly but does discuss how to reconnect } \\
\text { with biological family. }\end{array}$ \\
\hline $\begin{array}{l}\text { U of Southern- } \\
\text { Maine - N }\end{array}$ & Y & Y & Y & $\mathrm{Y}$ & $\begin{array}{l}\text { Describes the importance of connectedness in main- } \\
\text { taining sense of identity. }\end{array}$ \\
\hline $\begin{array}{l}\text { U of North } \\
\text { Carolina }-\mathrm{N}\end{array}$ & Y & Y & $\mathrm{Y}$ & $\mathrm{Y}$ & $\begin{array}{l}\text { Session } 7 \text { deals with connections as positive youth } \\
\text { development. Also Handout } 2 \mathrm{~b} \text { discusses positive } \\
\text { support relationships. }\end{array}$ \\
\hline $\begin{array}{l}\text { U of Oklahoma, } \\
\text { NRCYS }-{ }^{*} \mathrm{~N}\end{array}$ & $\mathrm{Y}$ & Y & $\mathrm{Y}$ & Y & $\begin{array}{l}\text { These are discussed in Section } 5, \text { "Four Core Prin- } \\
\text { ciples," and integrated throughout other sections, } \\
\text { but not a specific training module. }\end{array}$ \\
\hline $\begin{array}{l}\text { San Diego } \\
\text { State U }-{ }^{*} \mathrm{~N}\end{array}$ & $\mathrm{Y}$ & $\mathrm{Y}$ & $\mathrm{Y}$ & $\mathrm{Y}$ & $\begin{array}{l}\text { On a Micro level, looks at supports on the personal, } \\
\text { community and societal levels. }\end{array}$ \\
\hline $\begin{array}{l}\text { San Francisco } \\
\text { State U }\end{array}$ & $\mathrm{Y}$ & $\mathrm{Y}$ & $\mathrm{Y}$ & $\mathrm{N}$ & $\begin{array}{l}\text { Doesn't address permanency specifically. Con- } \\
\text { nections are talked about and discussed, but no } \\
\text { emphasis placed on how to use them or how to } \\
\text { make connections. }\end{array}$ \\
\hline SUNY - * & $\mathrm{Y}$ & $\mathrm{Y}$ & $\mathrm{Y}$ & $\mathrm{Y}$ & $\begin{array}{l}\text { Dedication of most of Module } 3 \text { to recruiting and } \\
\text { sustaining support systems including pulling } \\
\text { together LifePaks. }\end{array}$ \\
\hline
\end{tabular}

Current Support: addresses the issue of what supports are currently in place to assist in youth transition

Reconnect to Family: addresses youth desire/plan to reconnect with biological family while transitioning to IL

Connect to Foster Family: addresses how youth can maintain connections with foster family while transitioning to IL

New Connections: addresses how to recruit and sustain new supports before/during/after transitioning to IL

* = PowerPoint electronically available $\mathbf{N}=$ Detailed notes are available 


\begin{tabular}{|c|c|c|c|c|c|c|c|}
\hline Institution & 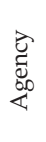 & 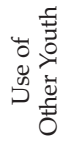 & 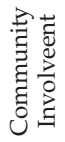 & 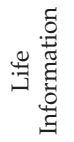 & 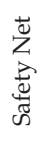 & $\frac{0}{0}$ & Comments \\
\hline Boston U & Y & Y & $\mathrm{N}$ & Y & $\mathrm{N}$ & $\mathrm{N}$ & $\begin{array}{l}\text { Looks at collaborations between worker and youth } \\
\text { to help with the engagement and empowerment } \\
\text { process. }\end{array}$ \\
\hline U of Denver & $\mathrm{Y}$ & $\mathrm{N}$ & $\mathrm{Y}$ & $\mathrm{Y}$ & $\mathrm{Y}$ & $\mathrm{Y}$ & $\begin{array}{l}\text { "Between Teens" is a module that identifies teens } \\
\text { with special needs and uses case studies to engage } \\
\text { participants in thinking about formal and informal } \\
\text { resources and partnerships. Community involve- } \\
\text { ment is limited to a directory of resources available } \\
\text { to youth and their workers. }\end{array}$ \\
\hline Fordham U & $\mathrm{N}$ & Y & Y & Y & $\mathrm{N}$ & $\mathrm{N}$ & $\begin{array}{l}\text { These issues are sprinkled throughout, but no set } \\
\text { focus on collaborations with others. }\end{array}$ \\
\hline U of Kansas - * & Y & Y & Y & Y & $\mathrm{Y}$ & $\mathrm{Y}$ & $\begin{array}{l}\text { Curriculum provides areas of collaboration, though } \\
\text { this is not one of the stronger areas. }\end{array}$ \\
\hline $\begin{array}{l}\text { U of Southern- } \\
\text { Maine - N }\end{array}$ & Y & Y & Y & Y & $\mathrm{Y}$ & $\mathrm{N}$ & $\begin{array}{l}\text { Curriculum provides workers with ways to collabo- } \\
\text { rate with youth and vice versa. }\end{array}$ \\
\hline $\begin{array}{l}\text { U of North } \\
\text { Carolina - N }\end{array}$ & $\mathrm{Y}$ & $\mathrm{Y}$ & Y & Y & $\mathrm{Y}$ & $\mathrm{Y}$ & $\begin{array}{l}\text { Session } 7 \text { builds on the importance of community } \\
\text { partners and resources. }\end{array}$ \\
\hline $\begin{array}{l}\text { U of Oklahoma, } \\
\text { NRCYS }-{ }^{*} \mathrm{~N}\end{array}$ & $\mathrm{Y}$ & $\mathrm{N}$ & Y & Y & $\mathrm{Y}$ & $\mathrm{Y}$ & $\begin{array}{l}\text { "Assessing Community and Tribal Resources" (p. } \\
\text { 137-139): Explores formal (agency) and informal } \\
\text { resources. Discusses ICWA policy at length. }\end{array}$ \\
\hline $\begin{array}{l}\text { San Diego } \\
\text { State } U-{ }^{*} \mathrm{~N}\end{array}$ & $\mathrm{Y}$ & Y & $\mathrm{Y}$ & Y & $\mathrm{Y}$ & $\mathrm{Y}$ & $\begin{array}{l}\text { Collaborative efforts are outlined mainly in p. 32-38 } \\
\text { and video clips of youth's views show how this } \\
\text { training makes collaboration work well. }\end{array}$ \\
\hline $\begin{array}{l}\text { San Francisco } \\
\text { State U }\end{array}$ & $\mathrm{Y}$ & $\mathrm{Y}$ & $\mathrm{N}$ & $\mathrm{N}$ & $\mathrm{N}$ & $?$ & $\begin{array}{l}\text { Content was developed cooperatively with foster } \\
\text { youth and intended to be delivered by youth. Policy } \\
\text { advocacy is addressed, but no specific policies are } \\
\text { included in the content. Includes handouts that } \\
\text { describe the services and eligibility criteria of local } \\
\text { programs, such as WIC, Head Start, TANF, etc. (p. } \\
\text { 109-114). }\end{array}$ \\
\hline SUNY - * & $\mathrm{Y}$ & Y & Y & Y & $\mathrm{Y}$ & $\mathrm{N}$ & $\begin{array}{l}\text { Use of Eco-Maps and positive examples of using } \\
\text { youth as partners in the Youth Development ap- } \\
\text { proach in Modules } 2 \text { and } 3 .\end{array}$ \\
\hline
\end{tabular}

Agency: addresses ways youth can collaborate within agency and with other agencies in the community Life Information: addresses how to obtain pieces of information youth will need during and after a transition Use of Other Youth: addresses ways youth can look to other youth for support and guidance for support Safety Net: addresses ways youth can create a contingency plan among resources and important people in their lives for support

Community Involvement: addresses ways youth can become involved in their communities to help meet their needs during/after a transition

Policy: addresses ways state/federal government has changed due to advocacy and/or ways youth can promote policy change

* = PowerPoint electronically available $\mathrm{N}=$ Detailed notes are available 
Table 4: Youth Development

\begin{tabular}{|c|c|c|c|c|c|c|c|c|c|c|}
\hline Institution & 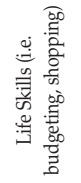 & 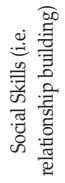 & 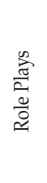 & 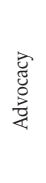 & 营 & 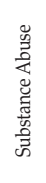 & 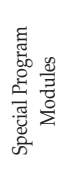 & 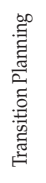 & 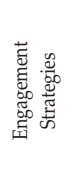 & Comments \\
\hline Boston $\mathrm{U}$ & Y & Y & $\mathrm{Y}$ & $\mathrm{Y}$ & $\mathrm{Y}$ & $\mathrm{Y}$ & $\mathrm{N}$ & $\mathrm{Y}$ & Y & $\begin{array}{l}\text { Uses Decide, Obtain, Maintain, Grow - } \\
\text { (DOMG) framework to provide steps to } \\
\text { guide thinking, planning and action toward } \\
\text { a successful transition. }\end{array}$ \\
\hline U of Denver & Y & $\mathrm{Y}$ & $\mathrm{Y}$ & $\mathrm{N}$ & $\mathrm{N}$ & $\mathrm{Y}$ & $\mathrm{Y}$ & $\mathrm{Y}$ & $\mathrm{N}$ & $\begin{array}{l}\text { Social skills are taught in the Emotional } \\
\text { Intelligence curriculum. Heavy focus on } \\
\text { decision-making and managing risks. }\end{array}$ \\
\hline Fordham U & $\mathrm{N}$ & Y & $\mathrm{Y}$ & Y & Y & $\mathrm{N}$ & Y & $\mathrm{Y}$ & $Y$ & $\begin{array}{l}\text { These functions are looked at in a general } \\
\text { overview throughout, a very good Module } \\
\text { on Adolescent Sexual Development. }\end{array}$ \\
\hline U of Kansas - * & Y & $\mathrm{Y}$ & $\mathrm{N}$ & $\mathrm{Y}$ & $\mathrm{N}$ & $\mathrm{N}$ & $\mathrm{N}$ & $\mathrm{Y}$ & $Y$ & $\begin{array}{l}\text { Does not mention substance abuse. Mentions } \\
\text { advocacy but does not provide skills. }\end{array}$ \\
\hline $\begin{array}{l}\text { U of Southern } \\
\text { Maine - N }\end{array}$ & $\mathrm{N}$ & Y & $\mathrm{Y}$ & $\mathrm{Y}$ & $\mathrm{N}$ & $\mathrm{N}$ & $\mathrm{N}$ & $\mathrm{Y}$ & $Y$ & $\begin{array}{l}\text { In terms of skills, focus was on communica- } \\
\text { tion skills of both youth and workers. }\end{array}$ \\
\hline $\begin{array}{l}\text { U of North } \\
\text { Carolina - N }\end{array}$ & $\mathrm{N}$ & $\mathrm{Y}$ & $\mathrm{Y}$ & $\mathrm{N}$ & $\mathrm{N}$ & $\mathrm{N}$ & $\mathrm{N}$ & $\mathrm{Y}$ & Y & $\begin{array}{l}\text { Matrix is provided showing what youth } \\
\text { need and strategies to achieve. }\end{array}$ \\
\hline $\begin{array}{l}\text { U of } \\
\text { Oklahoma, } \\
\text { NRCYS }-{ }^{*} \mathrm{~N}\end{array}$ & Y & Y & $\mathrm{Y}$ & $\mathrm{N}$ & $\mathrm{N}$ & $\mathrm{N}$ & $\mathrm{Y}$ & $\mathrm{Y}$ & Y & $\begin{array}{l}\text { Uses "tangible" for Life Skills and "intan- } \\
\text { gible" for Social Skills. }\end{array}$ \\
\hline $\begin{array}{l}\text { San Diego } \\
\text { State } U-{ }^{*} \mathrm{~N}\end{array}$ & $\mathrm{Y}$ & Y & $\mathrm{Y}$ & $\mathrm{Y}$ & $\mathrm{Y}$ & $\mathrm{N}$ & Y & $\mathrm{Y}$ & $\mathrm{Y}$ & $\begin{array}{l}\text { Although lacking a focus on substance abuse } \\
\text { issues, youth development issues are dis- } \\
\text { cussed throughout the training at all levels } \\
\text { - Macro, Mezzo and Micro. }\end{array}$ \\
\hline $\begin{array}{l}\text { San Francisco } \\
\text { State U }\end{array}$ & $\mathrm{N}$ & Y & $\mathrm{Y}$ & $\mathrm{Y}$ & $\mathrm{Y}$ & $\mathrm{N}$ & Y & $\mathrm{Y}$ & Y & $\begin{array}{l}\text { Utilizes role-plays throughout the cur- } \\
\text { riculum. Each module demonstrates unique } \\
\text { engagement strategies, emphasizing "teach- } \\
\text { able moments". }\end{array}$ \\
\hline SUNY - * & $\mathrm{N}$ & Y & $\mathrm{Y}$ & $\mathrm{Y}$ & Y & $\mathrm{Y}$ & $\mathrm{N}$ & $\mathrm{Y}$ & $\mathrm{Y}$ & $\begin{array}{l}\text { Emphasis here is on Assessment of Needs } \\
\text { (module 1), and using a strengths-based ap- } \\
\text { proach in working with high-risk youth. }\end{array}$ \\
\hline
\end{tabular}

Life Skills: addresses the hard or "tangible" skills youth should possess prior to emancipation (ex. budgeting, how to interview, how to buy healthy food, etc)

Social Skills: addresses soft or "intangible" skills youth need to possess prior to emancipation (ex. problem-solving skills, social skills, anger management, etc)

Role Plays: are role-plays offered to assist youth in understanding "real life" and/or are role-plays offered to help workers understand what transitions are like for youth

Advocacy: addresses if the training promotes self-advocacy or advocacy for foster youth in a broader text

Attitude: discusses how to work with youth who are difficult to work with

Substance Abuse: the training addresses substance use/abuse issues

Transition Planning: describes a transition plan or how to create one

Special Program Modules: other issues that may be given special attention

Engagement Strategies: discusses how to encourage youth involvement in their own lives

* = PowerPoint electronically available $\mathrm{N}=$ Detailed notes are available 


\section{University of Denver}

Strengths: This curriculum identifies and utilizes existing resources from other organizations. They include ordering or bibliographical information to make it easier to obtain the same resources (i.e., videotapes). Each module contains handouts, PowerPoints, and detailed trainer's notes. Unique to this curriculum is a module specifically for training professionals about youth who are differently-abled, but do not meet the disability criteria. Each module contains helpful role-plays, scenarios, and group activities.

Weaknesses: The curriculum does not include ideas for engaging youth in their transition planning, nor does it address attitudes and advocacy issues. Nearly all of the curriculum is focused on what social workers do, or behavior of social workers, in relation to how their actions may influence the youth they work with.

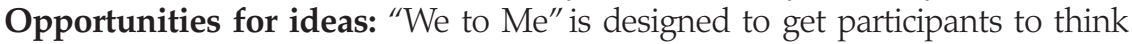
about how culture influences youth learning independent skills. Knowledge tests accompany each module. The "Cultural Mix" module has several case scenarios and role-play skits. Section III of "Planning in Advance" module refers to using a video developed by Eastern Michigan University under the same grant (Section III, p.2). Section IV of "Planning in Advance" module refers to a video about youth speaking on the loneliness of being emancipated without permanency and the importance of youth to have connections. The film was developed by the Casey Foundation and the state of Colorado (Section IV, p.2). A detailed description of how youth with special needs respond to help can be found on pp.9-13 of" Between Teens" module."In Our Own Voices: Foster Youth Tell of Life in Care" video referred to in "Problems Solvers" module on p.6. The video has 10 digital stories developed by foster youth, of which two are integrated into the curriculum. "What do we know about youth mental health and substance use" quiz about research findings is found on p.3 of that module.

Training techniques: Handout I-is a group activity to be used as an icebreaker for introducing cultural competence. Handout I-e can be read as a skit for a large group activity to explore spirituality and religion as part of cultural competence. Handout I-g describes the stages of Cultural Sensitivity. Handout II-a trains on ethnographic interviewing in child welfare."Planning in Advance" module trains on emotional intelligence (section II). Section IV of this module trains on connections. Substance abuse and mental health training is synthesized and included in the "Youth as Problem Solvers" module.

\section{Fordham University}

Strengths: Although this training is facilitated by professionals, it notes having had collaborative youth involvement to help create this training to represent the youth voice. In Box 1, \#11 Fordham provides a great chart looking at adolescent development of physical, emotional, cognitive, social, and moral as well as the tasks, attitudes and behaviors associated with that as well as the impact of foster care on this development. Also provided is an exercise to help us see that looks can be 
deceiving (Box 3, \#3). Fordham offers a module on adolescent sexuality and sexual development which can be found in Box 2. In Box 4 we find some nice assessment tools and \#6 outlines the S.M.A.R.T. goals for creating challenging but attainable personal goals for youth.

Weaknesses: Greater attention to organizing this training could have been useful as well as bringing a clearer focus to the cultural competency piece. Although cultural competence is mentioned and tended to, there is not a good deal of information there. Another struggle is with the lack of planning for permanent connections for greater support and well-being.

Opportunities for training: The "Choosing Partners" exercise in Box 3, \#3 is a great exercise to help you see where your own biases may lie and an activity entitled "Myth or Fact" in Box 2, \#4 is a great exercise for youth to discover that some of what they have been told about sexual development and sexuality may not be as valid as they thought.

Training techniques: The above mentioned activities are both challenging and interesting to add to any training. Many of the other techniques used in this training are handouts and blank worksheets (Box 4 \#4) that help to reinforce the material as well as giving the participant tangible resources to take with them and use with youth as appropriate. Another positive training technique used is by turning a common game show into an exercise in reinforcement; Independent Living Jeopardy (Box 1 \#15) is a great example of this.

Note: This curriculum is divided up into boxes and then numbered, so you will see notation to reference specific elements in Boxes 1,2,3 or 4 and then the number it is designated within that box. For example Box 1, \#1 discusses worker competencies.

\section{University of Kansas}

Strengths: Curriculum tends to be heavily focused on policy affecting IL youth. Competencies for the training were developed by Kansas youth.

Weaknesses: Training presents many ideas but not enough strategies to achieve goals. Skills are discussed in the last sessions of the curriculum but without procedure. Collaboration is a strong area in this training but needs more detail.

Opportunities for ideas: Ideas would be to mention more of the skills to achieve the goals and competencies presented.

Training techniques: Techniques include lecture and video segments.

\section{University of North Carolina}

Strengths: Positive youth development is a strong theme throughout training. Session 7 deals directly with youth development. A matrix is included outlining skills, health, employment support needs for youth, and strategies to achieve.

Weaknesses: Training seems to be too interactive at times without enough information being given to participants. This training needs to be more specific on culture as defining the person not the societal actions. 
Opportunities for ideas: More discussion would be helpful. Curriculum presents great ideas but it is unclear that everything is conveyed through the activities.

Training techniques: Video is created by youth, and discussion and activities accompany each session.

\section{The University of Oklahoma, NRCYS}

Strengths: Section 12, "Culturally Competent Teaching Strategies" (pp.86-91) focuses largely on how to engage youth in the training of life skills. The curriculum is laid out well and is very organized with a detailed trainer's manual and a second, complimentary participants' manual, which has several worksheets to engage trainees in active learning processes. They used very clear objectives in most sections and tied most sections to a defined competency.

Weaknesses: Advocacy is not clearly linked to training materials, nor is it linked to any of the competencies identified in the content. Its presence, though, can be found in pages 111-115. Permanent Connections are addressed on a global "resources" aspect, rather than establishing a permanent home post emancipation. Independence is emphasized as an investment in the community rather than establishing connections with individuals or creating a support network for future safety nets. They do, however, discuss the influences of past connections. Life information is very subtle and hidden in assessments and goal planning. Safety nets are mentioned, but not specifically trained.

Opportunities for ideas: A "tear-jerker"letter from a child in custody is found in the participant manual's appendix, pages 76-77. The letter is useful in demonstrating what it might be like to transition out of care after a long period of foster care drift. The Module, "Four Phases of Life Path" (pp.80-85) are great training ideas when having participants explore culturally-related concepts in the life course of adolescents. The module, "Naturalistic Inquiry," (pp.133-136) is a solid beginning step to help youth start thinking about setting goals. Entire sections are devoted to "Indian Child Welfare Act" and "Historic Distrust" (pp.56-66). This information can be useful to integrate into other curricula for inclusion of the Native American race in the development of cultural competence training.

Training techniques: "Minefield" (pp.108-111) is a learning activity that uses role-plays and physical movement to simulate youth navigating the child welfare system. This would be a great activity to bring out barriers to local community services, language and cultural barriers, and other challenges associated with transitioning. Another similar group role-play is found on page 97. Several times throughout the training, the facilitator asks the participants to practice using tools (worksheets) in the manual during the training.

\section{San Diego State University}

Strengths: The training is structured by breaking down the issues into three major levels-Macro, Mezzo, and Micro levels. This plays well for coordinating all 
areas of need for youth in transition, looking at policy all the way down through making permanent connections for personal support. A wide array of need is covered, yet one does not feel overwhelmed by the broad spectrum due to positive organization. Two binders accompany this main training, one for the participant and one for the trainer. The trainer version has greater details on instructions for activities and also includes "Trainer Tips" for additional information or to help keep moving a discussion along if stuck, while the participant binder has all the needed resources to share with the youth with whom they work. A third binder helps guide participants through a simulation called "Teen Time" which helps workers"walk a day in the life" in another role. Although youth are not the main facilitators of this training, a youth panel is an optional activity and via video clips, a strong youth voice is present throughout the training.

Weaknesses: More attention could be given to the special issues such as substance abuse, mental health and obtaining more of the supports needed to obtain or maintain health in those areas.

Opportunities for training: The use of the simulation "Teen Time" is a great way for workers to put themselves in different roles to help acknowledge how many different players the youth is juggling. The use of the video clips (present throughout the training) is a positive way to infuse a youth voice on varying issues. Another positive use of a case study is introduced to us (initially on page 64 of the trainer binder) and used throughout the training as a tool to look at adolescent development and assessment (p.106 trainer binder) for examples.

Training techniques: If possible to gather a youth panel and prepare them as San Diego did, this can prove to be a great strength for sending a strong message (p.19 participant, p.24 trainer), and again the video clips tell a story in youth's own words as well. Revisiting one case study throughout the training helps to bring familiarity to the case as well as using different skills as one would with their own clients. This training keeps the participants involved by asking for volunteers for group discussions, role-plays (i.e. Teen Time) and reflections on their own work-helps to keep the group tuned in and eager to hear more. Finally, this training ends with a powerful exercise called, "Web of Support" (p.113, trainer) where participants are in a circle and while stating what they commit to do for youth in care they pass around a ball of string or yarn, making a "web of support".

\section{San Francisco State University}

Strengths: Chapter 3 describes the 10-step curriculum development process. A 4-step development process is illustrated on page 31 with a helpful debriefing/ evaluative worksheet. The curriculum places a strong emphasis on attitudes and values reconstruction. Each unit uses active learning strategies to engage participants in the training and helps participants identify with the youth they serve and the discrimination issues the youth face.

Weaknesses: While the depth of the cultural competence is a strength, the 
curriculum is lacking in breadth. There is very little content about teaching policy issues, life skills, and establishing permanency. There is a heavy emphasis on getting participants to identify with what the youth have been though in the past, but little focus on how to help them plan for the future. Most content is past and present focused, and extremely limited in forethought and transitional planning. There is "overkill" on creative teaching and the teaching moments theme. This curriculum is lacking in substantive content on the issues youth face. For example, "Buying Time" skit (p.50-54) seems to be an example of how social workers shut out their clients, but it's not very useful for training supervisors unless you modify the skit to be an interaction between supervisor and supervisee-and then it's not clear what the purpose of doing it is for.

Opportunities for ideas: Includes information on foster youth rights and a glossary of terms at the end of the manual. Samples of youth testimonials are found throughout the curriculum. "Foster Youth Testimonials" module (pp.55-62) addresses the effects of labeling youth. A module about story-telling is found on pages 63-67, which engages youth by using life experiences to create teachable moments. The entire curriculum seems to be based on a symbolic-interactionist approach. For example, "People Hunt" (pp.90-95) is a module created to develop awareness about the labeling and diagnostic process and its effects on youth.

Training techniques: The communication skills module (pp.68-73) uses a learning activity called "Life ${ }^{\mathrm{TM}}$ Cereal Rebate Offer". A module on attitudes impacting social work with youth uses a Treasure Hunt training technique (pp.115118). "Super Social Worker" module (pp.119-121) involves a learning activity where workers diagram their qualities as social workers on a self-portrait. "Recognizing Resources" includes a tool that makes learning about community resources a game (pp.106-107). "Milestones" is a survey tool identifying the transitioning youths' milestones combining a visual and narrative technique (p. 77-78). "What Comes to Mind" is a learning activity asking participants to reflect on stereotypes through word and thought association (pp.140-142). "Taboo" is a module that exposes social workers to the challenges of gay foster youth (pp.131-139). Digital storytelling is taught using "mind maps" while viewing video clips (pp.43-47).

\section{University of Southern Maine}

Strengths: Advocacy session that described the need and provided strategies. The coaching session was also useful as another way to look at the supports youth need. This training offers many handouts at the end of each session that are useful for participants to take home and use with youth.

Weaknesses: Skill-building was a weaker area. In the coaching session, the importance was placed upon communication skills. This left out many crucial skills needed by youth.

Opportunities for ideas: Improving the weaker areas of training such as culture and skill-building would make this an important knowledge base for positive 
youth development among workers.

Training techniques: Techniques include discussion, activities, video, and books.

\section{SUNY}

Strengths: This training is broken down into 3 well-organized Modules of PowerPoint slides with explicit steps for introducing the material and has all of the handouts and worksheets available as attachments. A strong focus is on the needs of high-risk youth, using Strengths-Based (Module 1, slide 25) and Youth Development (Module 1, slide 45) approaches for effectively working with youth. Module 2 looks at Substance Abuse and Prochaska's Stages of Change (Module 2 , slide 18, plus handouts) which is a great assessment tool when looking at a youth's readiness to change certain behaviors. Module 3 focuses on recruiting and sustaining supports for high risk youth and possible reasons why youth may be resistant and how to work with them in overcoming a fear of connections (Module 3, slides 7-12), while creating contingency plans and safety nets (Module 3, slides 23-31).

Weaknesses: This training lacks any focus on cultural competence and does not provide any of the hard/life skills needed for a positive transition into independent living - unless one decides to use the LifePak in this regard, but specifics are not given here. This training appears to be lacking in teaching "real life" skills youth will need to have to transition to life on their own. The overall focus on this training is how to best support youth while still in care; little attention is given to the actual time of transition and transition readiness.

Opportunities for training: One activity seemed to stand above the rest. In Module 3, slide 32 participants completed a resource activity; dividing up the group into 4 and putting paper around the room with different needs (ex. mental health, substance abuse, sexuality, violence-or other pertinent needs) and the participants create a resource list that can later be helpful to youth as well as their workers-a collaborative effort in discovering resources in the area. Another great idea to help participants know what it feels like to move from different foster families and even from foster care into independent living is an activity called "Independent Living Human Machine" (Module 1, slide 17).

Training techniques: SUNY offers a pre- and post-test as a way for both participants and trainers to assess the effectiveness of the training in terms of gaining knowledge, but this is an optional inclusion. Many worksheets and handouts can be found in the attachment for each module as well as activities like those mentioned above. A "Reframing" activity (Module 1, slide 30) looks at taking statements or phrases we might use and, with a partner, make those statements more neutral or positive. They use a case example and have the trainers perform a skit with a review (Module 2, slide 19). Use of Eco-Maps (Module 3, slide 5, 6), safety net, and a"Minefield" exercise (Module 3, slide 29) where one participate acts as a youth trying to make their way to self-sufficiency while dealing with obstacles along the way. 
Finally, use of the LifePaks that youth take the lead in creating and have something tangible to take with them upon aging out.

Note: This training is divided into Modules according to the PowerPoint, so rather than referencing page numbers, this will refer to the module and the PowerPoint slide where you can find additional information.

\section{Value of Analyses}

The matrices and SWOT analyses were used by our project teams to help in the creation of our supervisory training. It would have been ideal to add to this matrix the findings from the grantee training evaluations to show if there was any evidence that the content and delivery methods utilized were a) helpful in creating positive trainee reactions, particularly in the form of seeing the training as useful (c.f., Antle et al., in press), b) helpful in increasing learning from before to after the training (c.f., Sullivan, Antle, \& Barbee, 2009), especially as compared to a control group, c) helpful in facilitating learning transfer from the classroom to the field (c.f., Antle, Barbee, \& van Zyl, 2008, Antle, Christensen, Barbee, \& Martin, 2008) and d) helpful in making a difference in the lives of the clients of the workers who participated in the training as opposed to those who were served by workers who did not participate in the training (c.f., Antle et al., in press). The next article in this special issue will address the efficacy of these trainings, but unfortunately, the data were not available at the time our teams were gathering information in order to write our own curricula. One implication of this is that the Children's Bureau should encourage firms like James Bell Associates who have the contract to oversee a set of discretionary grants to create, at the conclusion of the granting period, a document that focuses on this type of critique of the curricula and include a section on evaluation results for each curricula in the SWOT analysis. That way, other states that are trying to discern which curriculum is best to adopt in their states can have the information necessary to choose wisely.

This information was particularly important for the curricula development in Kentucky because the goal was to train supervisors with their teams so that these supervisors could assess the strengths and concerns for their workers and serve as both trainees and mentors during the actual training (Antle, Barbee, \& van Zyl, 2008). That way our project was able to train supervisors and front line workers as well as other partners (foster parents, private child care providers serving youth aging out of care, and community partners).

We hope in publishing this critique that it will serve as a tool for a) critiquing other curricula for the benefit of creating a new one, b) critiquing one's own curricula, c) external training evaluators to use as a part of the overall evaluation process (Antle, Barbee, \& van Zyl, 2008) and d) summarizing curricula content as a part of Children's Bureau marketing efforts. 


\section{References}

Antle, B. F., Barbee, A. P., \& van Zyl, M. A. (2008). A comprehensive model for child welfare training evaluation. Children and Youth Services Review, 9, 10631080.

Antle, B. F., Christensen, D., Barbee, A. P., \& Martin, M. (2008). Solution-based casework: A paradigm shift to effective, strengths-based practice for child protection. Journal of Public Child Welfare, 2, 197-227.

Antle, B. F., Barbee, A. P., \& Van Zyl, M. A. (2009). Supervision in child welfare practice. In C. Potter \& C. Brittain (Eds.), Supervision in Child Welfare, Oxford Press.

Antle, B. F., Sullivan, D. J., Barbee, A. P., \& Christensen, D. N. (in press). The effects of training methodology on training transfer. Child Welfare.

Antle, B. F., Barbee, A. P., \& Christensen, D. N. (in press). The prevention of child maltreatment recidivism through the solution-based casework model of child welfare practice. Children and Youth Services Review.

Sullivan, D.J., Antle, B.F., Barbee, A.P., \& Egbert, R. (2009). The use of training for best practice in public welfare. Public Administration Review. 